\title{
GENETIC MERIT OF POPCORN LINES AND HYBRIDS FOR MULTIPLE FOLIAR DISEASES AND AGRONOMIC PROPERTIES
}

(D) Juliana Saltires Santos ${ }^{1 *}$, (D) Yure Pequeno de Souza ${ }^{1}$, (D) Marcelo Vivas ${ }^{2}$, (iD) Antônio Teixeira do Amaral Junior ${ }^{1}$, (iD Janeo Eustáquio de Almeida Filho ${ }^{1}$, (D) Gabrielle Sousa Mafra ${ }^{1}$, (D) Alexandre Pio Viana ${ }^{1}$, (D) Geraldo de Amaral Gravina $^{2}$, (i) Fernando Rafael Alves Ferreira ${ }^{1}$

1 Laboratório de Melhoramento Genético Vegetal, Universidade Estadual do Norte Fluminense Darcy Ribeiro (UENF), Campos dos Goytacazes, RJ, 28013-602;

2 Laboratório de Engenharia agrícola, Universidade Estadual do Norte Fluminense Darcy Ribeiro (UENF), Campos dos Goytacazes, RJ, 28013-602.

*Corresponding author: Juliana Saltires Santos (julianasaltiresdossantos@yahoo.com.br)

\begin{abstract}
Popcorn lines with genetic resistance to foliar diseases allow the production of higher yields at lower costs. Thus, the development of resistant genotypes becomes essential, while the selection efficiency of parents and hybrids depends on the existence of genetic variability and knowledge about the genetic trait control. The objective of this study was to determine the genetic merit of the hybrid lines and genotypes, as well as the reciprocal effect; to draw conclusions on the genetic control of the traits of disease incidence and severity associated with resistance to Exserohilum turcicum, Bipolaris maydis, Puccinia polysora and of the agronomic traits grain yield and popping expansion; and to assess the effects of the trait interrelations on parent and hybrid selection. Fifty-six hybrid combinations ( $F_{1}$ and reciprocal crosses) were evaluated in two growing seasons. A randomized block design with four replications was used. Regardless of the growing season, the non-additive genetic component had the greatest influence on the studied traits, whereas no reciprocal effect was observed. The performance of lines L61, L70 and L76 was good in both growing seasons by increasing the level of multiple disease resistance associated with high gains in GY and PE. The hybrids L61 x L76; L61 x L77; L76 x P1 were the most promising of the tested crosses for cultivation in both seasons, targeting a decrease in the levels of several diseases and higher grain yields and popping expansion.
\end{abstract}

Keywords: Zea mays, genetic control, disease resistance, genotype selection. 


\section{Introduction}

Popcorn (Zea mays L.) is a specialty maize that is widely consumed in Brazil and cultivated on a large scale by the country's farmers, mainly due to the higher economic value than that of field maize (Vieira et al., 2011; Amaral Júnior et al., 2016; Ribeiro et al., 2016). However, this crop shows is highly susceptible to pests and diseases and attacked by numerous pathogens causing foliar diseases, which can significantly reduce grain yield and quality (Ribeiro et al., 2016; Kurosawa et al., 2017).

Among the leaf diseases that affect popcorn, one can highlight leaf spots caused by the fungi Exserohilum turcicum (Pass.) Leonard $\&$ Suggs (synonym Helminthosporium turcicum Pass.) and Bipolaris maydis (Nisik.) Shoemaker (synonymous with Helminthosporium maydis Nisik) as the two main diseases (Ishfaq et al., 2014; Wang et al., 2014; Hurni et al., 2015; Amaral Júnior et al., 2016; Kurosawa et al., 2017). Under favorable climatic conditions associated with susceptible hosts, grain yield losses of 27 to $90 \%$ caused by E. turcicum are reported (Ferguson and Carson, 2007; Muiru et al., 2010; Wang et al., 2010; Ding et al., 2015) and of about $70 \%$ for $B$. maydis (Hussain et al., 2016; Mubeen et al., 2017).

Another important disease is American corn rust, caused by Puccinia polysora (Underwood), in which this fungus significantly reduces the photosynthetic capacity of the plants, occasionally causing premature leaf senescence and, consequently, productivity losses. This disease can induce a productivity loss of up to $65 \%$, particularly in areas where occurrence of the disease has been reported in the past (Costa et al., 2012; Teixeira et al., 2017).

To reduce the problems of yield losses in this scenario, an important strategy is the development of cultivars with genetic resistance to the main diseases (Vieira et al., 2009; AyigaAluba et al., 2015; Ding et al., 2015; Chen et al., 2016; Ribeiro et al., 2016; Amaral Júnior et al., 2016; Kurosawa et al., 2017). To this end, the study of the combining abilities of the previously selected parents is an essential step in the optimization of breeding strategies. In this regard, the diallel crosses constitute feasible options for this purpose (Hallauer et al., 2010).

Combining ability studies indicate that the genetic effect for resistance to E. turcicum may consist of additive (Carson, 1995; Vivek et al., 2010; Kaefer et al., 2017) or, predominantly, non-additive gene effects (dominance and/or epistasis) (Carson, 2006; Ogliari et al., 2007; Nihei and Ferreira, 2012). According to Vieira et al. (2009), the two effects together may also be important in the genetic control of the disease. Additive and non-additive effects, respectively, were also observed for B. maydis (Kumar et al., 2016) and P. polysora (Colombo et al., 2014), but the additive effects are reported to be more influential in most studies focused on the inheritance of resistance to these diseases.

Differences in the genetic trait control may occur due to the population involved in diallel crosses (Oliveira et al., 2011) or due to environmental variations. In a diallel analysis of the combining ability of parents, Engelsing et al. (2011) and Nihei and Ferreira (2012) observed that the components of GCA and SCA varied according to the environment. Therefore, there is a notable lack of consistent information to guide direct breeding programs for popcorn leaf diseases under distinct cultivation conditions.

Thus, the objective of this study was to determine the genetic value of popcorn lines and the genotypic value of hybrids, as well as the reciprocal effect, to draw conclusions on the genetic control of traits associated with resistance to E. turcicum, B. maydis, and $P$. polysora and of the agronomic traits grain yield and popping expansion in popcorn lines crossed in a diallel mating scheme and evaluated in two growing seasons, as well as to assess the effects of trait interrelations on the selection of parents and hybrids.

\section{Material and methods}

For this study, eight lines (L88, L77, L76, L70, L55, L61, P8 and P1) in the seventh selfing generation $\left(\mathrm{S}_{7}\right)$ (Table 1) were crossed in a complete diallel mating design, according to the methodology proposed by Griffing (1956), including the reciprocal crosses, resulting in 56 hybrid combinations. 
Table 1. Parent popcorn lines used in a complete diallel scheme with the reciprocal crosses, resulting in 56 hybrid combinations.

\begin{tabular}{cccc}
\hline Genotypes & Original variety & Climate adapatation & Institution desenvolvimento \\
\hline P8 & Hybrid IAC-112 & Temperate/Tropical & UEM \\
\hline P1 & Triple hybrid Zelia & Temperate/Tropical & UEM \\
\hline L55 & Beija-flor & Temperate/Tropical & UENF \\
\hline L61 & BRS-Angela & Temperate/Tropical & UENF \\
\hline L70 & BRS-Angela & Temperate/Tropical & UENF \\
\hline L76 & Viçosa & Temperate/Tropical & UENF \\
\hline $\mathbf{L 7 7}$ & Viçosa & Temperate/Tropical & UENF \\
\hline L88 & Viçosa & Temperate/Tropical & UENF \\
\hline
\end{tabular}

UEM = Universidade Estadual de Maringá; UENF = Universidade Estadual do Norte Fluminense Darcy Ribeiro.

The diallelic hybrids, together with the parent lines, were evaluated in experiments performed in two growing seasons: first season (October 2014 to January 2015), at a mean temperature of $25^{\circ} \mathrm{C}$ and mean air humidity of $73 \%$, and the second season (April to July 2015), at a mean temperature of $22{ }^{\circ} \mathrm{C}$ and mean humidity of $82 \%$.

The experiments were carried out in an experimental area of the State University of Northern Rio de Janeiro (UENF), of the Antônio Sarlo State College, Campos dos Goytacazes, in the northern region of the State of Rio de Janeiro, Brazil. The experiment was arranged in a randomized block design with four replications. Experimental plots consisted of single 5-m rows with 25 plants per row and spaced $0.2 \times 0.9 \mathrm{~m}$ between plants and rows, respectively. At sowing, the plots were fertilized with $60 \mathrm{~kg} \mathrm{ha}^{-1}$ $\mathrm{K}_{2} \mathrm{O}, 30 \mathrm{~kg} \mathrm{ha}^{-1} \mathrm{~N}$, and $60 \mathrm{~kg} \mathrm{ha}^{-1} \mathrm{P}_{2} \mathrm{O}_{5}$, and 100 $\mathrm{kg} \mathrm{ha}^{-1} \mathrm{~N}$. Irrigation was provided by sprinkler irrigation and herbicide and insecticide were applied whenever necessary.

The following foliar diseases were evaluated: leaf spots caused by the pathogens $B$. maydis and E. turcicum and American corn rust caused by the pathogen Puccinia polysora, manifested by natural pathogen infection in the field. The performance of the genotypes under disease pressure was monitored by estimates of incidence - proportion of injured leaves, in relation to all leaves of the plant, expressed as percentage, and severity - quantified by the percentage of diseased leaf area along the first leaf below the first ear.

The following procedure was used for these evaluations: of the 25 plants in the experimental plot, the five first and five last plants were eliminated, and the 15 central plants were considered for evaluation. The first plant of the evaluation plot was marked and assessed and the following two were omitted, subsequently repeating the procedure. In this way, five plants per plot were evaluated and the mean of three evaluations, in intervals of seven days after female flowering, was calculated.

The incidence of $B$. maydis (IBM), $E$. turcicum (IET) and $P$. polysora (IPP) was evaluated visually on the grading scale proposed by Agroceres (1996). On this 1-9 score scale, score 1 indicates $0 \%$ incidence; 2 - $0.5 \%$ incidence; 3 - 10\% incidence; 4 - 30\% incidence; 5 - 50\% incidence; 6 - 70\% incidence; 7 - 80\% incidence; $8-90 \%$ incidence and $9-100 \%$ disease incidence.

The severity was assessed visually on a disease-specific diagrammatic scale. Thus, the severity of B. maydis (SBM) was estimated on a diagrammatic scale with percentages of $1,5,25$ and $50 \%$ of injured leaf area, according to the methodology of James (1971). The severity of $E$. turcicum (SET) was estimated on the diagrammatic scale based on the percentage values $0.5,1.6,5.0,15,37,66,87,96 \%$ of the injured leaf area (Viera et al. 2014). The severity of Puccinia polysora (SPP) was estimated on a diagrammatic scale Cobb modified (Chester, 1950), based on percentage values between 5 and $100 \%$ of the injured leaf area.

The agronomic traits grain yield (GY) and popping expansion (PE) were also evaluated. The GY was determined by weighing the grains after removing the cob and expressed in kg.ha- ${ }^{-1}$. Popping expansion was determined by averaging 
two replications per treatment, each one represented by $30 \mathrm{~g}$ grains. The grains were popped in a microwave oven at $1,000 \mathrm{~W}$, for 2 min $20 \mathrm{sec}$. After expansion, the popcorn volume was quantified in a $2,000 \mathrm{~mL}$ beaker, and the final result was adjusted relative to the initial weight of 30 grams, expressed in $\mathrm{mL} / \mathrm{g}$.

The following model was used for the statistical analysis:

$$
\begin{aligned}
& y_{i j k l}=\mu+e_{l}+b_{k}\left(e_{l}\right)+g_{1_{i}}+g_{2_{j}}+s_{i j}+r_{1 i}+ \\
& r_{2_{j}}+g e_{1_{i l}}+g e_{2_{i l}}+s e_{i j l}+r e_{1_{i l}}+r e_{2 j l}+e_{i j k l}
\end{aligned}
$$

Where: $\mu=$ general constant; $e_{l}=$ fixed season effect; $b_{k}\left(e_{l}\right)=$ fixed effect of the block x season interaction; $g_{1_{i}}$ and $g_{2_{j}}=$ random effects of general combining ability (GCA) involving parents $i$ and $j$, where $g_{1_{i}}$ and $g_{2 j} \sim N\left(0, \sigma_{g}^{2}\right) ; s_{i j}$ $=$ random effects of the specific combining ability (SCA), involving the parents $i$ and $j$, where $s_{i j} \sim N\left(0, \sigma_{s}^{2}\right) ; r_{1_{i}}$ and $r_{2 j}=$ random effects of specific combining ability manifested in the reciprocal cross (RE) involving parents $i$ and $j$, where $r_{1_{i}}$ and $r_{2 j} \sim N\left(0, \sigma_{r}^{2}\right) ; g e_{1_{i l}}$ and $g e_{2_{i l}}=$ random effects of the interactions of general combining ability (GCA) $\mathrm{x}$ season, involving seasons $\mathrm{s} 1$ and $\mathrm{s} 2$, where $g e_{1_{i l}}$ and $g e_{2_{i l}} \sim N\left(0, \sigma_{g e}^{2}\right) ; s e_{i j l}=$ random effect of the interaction of specific combining ability (SCA) $\mathrm{x}$ season, involving seasons $\mathrm{s} 1$ and $\mathrm{s} 2$, where $s e_{i j l} \sim N\left(0, \sigma_{s e}^{2}\right) ; r e_{1_{i l}}$ and $r e_{2 j l}=$ random effects of the interactions of specific combining ability manifested in the reciprocal cross (RE) $\mathrm{x}$ season, involving the seasons s1 and s2, where $r e_{1_{i l}}$ and $r e_{2 j l} \sim N\left(0, \sigma_{r e}^{2}\right)$; and $e_{i j k l}=$ mean random residue $\mathrm{r}$ associated with observations $i j k l$, where $e_{i j k l} \sim N\left(0, \sigma_{e}^{2}\right)$.

The variance components were estimated by the REML method, using algorithm AI with package asreml (Butler, 2009), and the hypotheses on the components of genetic variance were tested with the likelihood ratio test (LRT) and Asreml + package (Brien, 2016).

To estimate the genetic merit of the lines, BLUPs of the general combining ability (GCA) of the parents were used, and the genotypic values of the hybrids were used to estimate the genetic merit of the hybrids, added to the overall mean of the trait in each season. Thus, the GCA of a parent in a given season was expressed by:

$$
G C A_{i l}=\mu+g_{1_{i}}+g e_{1_{i l}} \text { (Eq. 2) }
$$

While the genotype value of the hybrid for a given season $\left(h_{i j l}\right)$ is given by:

$$
h_{i j l}=\mu+g_{1_{i}}+g_{2_{j}}+s_{i j}+g e_{1_{i l}}+s e_{i j l} \text { (Eq. 3) }
$$

To obtain the relationship between the parent responses and the hybrid combinations in both evaluation periods, the correlations between the traits within each period/season were estimated. To this end, the BLUP values of the general combining ability (GCA) of the parents and the genotypic values of the hybrids were used. All genetic-statistical analyses were carried out using software R (R Core Team, 2014).

\section{Results and discussion Components of variance}

The effect of the variance component of SCA proved significant by the Likelihood Ratio Test (LRT) for incidence and severity of $E$. turcicum (IET and SET, respectively), incidence of B. maydis (IBM), grain yield (GY) and popping expansion (PE), indicating predominance of component SCA over component GCA for these traits (Table 2). These results suggest that the performance of certain hybrid combinations differs, which cannot be explained by simple parent means and their GCA, since the non-additive gene effects are more relevant for the control of these traits.

With regard to the genetic control of resistance to E. turcicum, some authors claimed that it is predominantly qualitative, with nonadditive effects (Carson, 2006; Ogliari et al., 2007; Nihei and Ferreira, 2012). The occurrence of variance components with predominance of non-additive effects found in this study suggests the possibility of developing new cultivars from crosses by exploiting the effect of allelic complementation more efficiently, with a view to improving E. turcicum resistance. On the other hand, some studies reported several genes with additive effects responsible for controlling the expression of E. turcicum resistance (Carson, 1995; Vivek et al., 2010; Kaefer et al., 2017). 
However, quantitative resistance can be influenced by additive and non-additive effects (Vieira et al., 2009).

The trait B. maydis incidence (IBM) differed statistically in the genetic variance components of the GCA and SCA effects (Table 2), indicating the existence of variability between the GCA effects associated with additive gene effects, and the SCA effects associated with non-additive gene effects. However, there is a predominance of SCA over GCA, demonstrating that the non-additive gene effects are more relevant in the control of this trait. In a QTL mapping study, Carson et al. (2004) observed that additive and non-additive gene effects play a role in the genetic control of $B$. maydis resistance in maize.

However, Kumar et al. (2016) stated that only the additive effects are essential for the genetic control of $B$. maydis resistance in tropical maize genotypes. Thus, it is suggested to consider both the additive and non-additive effects in the expression of the trait and, therefore, breeding methods that exploit both effects, e.g., interpopulation recurrent selection, are adequate strategies to develop B. maydisresistant cultivars.

Table 2. Combined analysis of variance components for the traits incidence and severity to E. turcicum (IET, SET), B. maydis (IBM, SMB), P. polysora (IPP, SPP), grain yield (GY) and (PE) in popcorn in two growing seasons.

\begin{tabular}{lcccccccc}
\hline \multirow{2}{*}{ Parameters } & \multicolumn{7}{c}{ Traits } \\
\cline { 2 - 8 } & IET & SET & IBM & SBM & IPP & SPP & GY & PE \\
\hline GCA & $0.00^{\text {ns }}$ & $2.08^{\text {ns }}$ & $10.68^{*}$ & $0.00^{\text {ns }}$ & $0.00^{\text {ns }}$ & $0.00^{\text {ns }}$ & $0.38^{\text {ns }}$ & $1.04^{\text {ns }}$ \\
\hline SCA & $68.69^{* *}$ & $2.71^{* *}$ & $18.41^{* *}$ & $0.00^{\text {ns }}$ & $0.00^{\text {ns }}$ & $0.04^{\text {ns }}$ & $1156418.00^{* *}$ & $4.57^{* *}$ \\
\hline RE & $0.00^{\text {ns }}$ & $0.00^{\text {ns }}$ & $0.00^{\text {ns }}$ & $0.00^{\text {ns }}$ & $0.00^{\text {ns }}$ & $0.01^{\text {ns }}$ & $0.04^{\text {ns }}$ & $0.00^{\text {ns }}$ \\
\hline GCA x Season & $40.66^{* *}$ & $0.87^{* *}$ & $3.55^{* *}$ & $0.09^{* *}$ & $2.96^{* *}$ & $1.03^{* *}$ & $24209.30^{*}$ & $1.66^{* *}$ \\
\hline SCA x Season & $22.39^{\text {ns }}$ & $0.82^{\text {ns }}$ & $2.26^{*}$ & $0.18^{* *}$ & $1.54^{*}$ & $1.86^{*}$ & $3304.20^{\text {ns }}$ & $1.65^{*}$ \\
\hline RE x Season & $0.00^{\text {ns }}$ & $0.01^{\text {ns }}$ & $0.00^{\text {ns }}$ & $0.00^{\text {ns }}$ & $0.00^{\text {ns }}$ & $0.39^{*}$ & $0.06^{\text {ns }}$ & $0.06^{\text {ns }}$ \\
\hline Residue & 57.92 & 9.91 & 2.26 & 0.13 & 31.63 & 16.58 & 583291.00 & 13.12 \\
\hline
\end{tabular}

**P $<0.01, * \mathrm{P}<0.05$ and ns non-significant by the LRT (Likelihood Ratio Test) test. GCA $=$ component of genetic variance of GCA effect; SCA = genetic variance component of the SCA effect, RE = component of the genetic variance of the reciprocal effect GCA x Season = interaction of the genetic variance component of the GCA with the season effect, SCA $\mathrm{x}$ Season $=$ interaction of the genetic variance component of the SCA effect with the season, RE $\mathrm{x}$ Season = interaction of the genetic variance component of the reciprocal effect with the season, Residue = component variance of the residue.

For grain yield, the predominance of the genetic variance components of the SCA effect on the trait indicated that the mean hybrid performance was better than that of the lines involved. Similar results were reported by Pereira and Amaral Júnior (2001), Rangel et al. (2007) and Oliveira et al. (2016), reinforcing the importance of non-additive effects for the expression of this trait.

For the set of parents in studies, the genetic component of variance for $\mathrm{PE}$ was predominantly non-additive. These results were also reported by Oliveira (2016), who observed the most important non-additive effects in the inheritance of this trait and recommended the exploration of hybrids for a significant increase in mean popcorn expansion. In four QTLs for popping expansion, Babu et al. (2006) and Li et al. (2007) found dominant, partially dominant and overdominant gene action. However, other authors demonstrated the greater influence of additive gene action to increase PE (Pereira and Amaral Júnior, 2001; Freitas Junior et al., 2006; Cabral et al., 2015). A possible explanation for this difference is that the genetic structure of a population can induce distinct gene actions for the same trait.

The genetic component of variance of the reciprocal effect $\mathrm{RE}$ was not significant for any of the traits evaluated (Table 2), showing that the hybrids and their reciprocals did not differ significantly, i.e., there would be no gains by inverting the order of parents in the crosses. The variance component of the RE $x$ season interaction for the trait $P$. polysora severity (SPP) was significant at $\mathrm{P}<0.05$; however, these estimates were low, which seems to be rather irrelevant for the resistance to this disease in the 
set of evaluated parents. Similar results were reported by Vieira et al. (2012), in an evaluation of maize diseases under different environmental conditions.

Highly significant differences $(\mathrm{p}<0.01)$ for most of the traits evaluated were also observed for the GCA x Season interaction (Table 2), showing that the environmental variations in both growing seasons resulted in differences in the mean parent performance, indicating the existence of season-specific parents. Thus, the estimated contribution of the additive gene effects should be expressed separately for each evaluation period. In a sense, these results had been expected, since the intensity and severity of the diseases vary according to the growing season (Kurosawa et al., 2016).

For the SCA $x$ Season interaction, the Likelihood Ratio (LRT) test detected significant differences for the variables IBM, SBM, IPP, SPP and PE (Table 2), showing a differentiated response of the genotypes in each season, with regard to the combining ability of the evaluated lines and hybrid performance (Niehi and Ferreira, 2012). In this situation, the genetic SCA components should also be analyzed separately for each environment. Other authors also described a significant interaction of the GCA and SCA effects with environments in studies related to disease resistance and maize yield (Paterniani et al., 2000; Carson, 2001; Lopes et al., 2007; Guimarães et al., 2009; Vivek et al., 2010; Niehi and Ferreira, 2012; Vieira et al., 2012).

\section{Genetic merit of the lines}

From parents selected based on the additive genetic merit, genotypes with a genetic potential to be phenotypically superior can be obtained. According to Cruz et al. (2012), high positive or negative GCA values indicate that the parent is far superior or inferior to the other parents used in the diallel.

Based on the estimates of the additive genetic merit (GCA), which corresponds to the predicted estimates (GCA + GCA x Season) added to the overall trait mean, it was observed in the first season that the lines L61 and L70 stood out with the lowest GCA estimates for the traits related to resistance to E. turcicum, $P$. polysora and B. maydis (incidence and severity) (Table 3).

Table 3. Estimates of the additive genetic merit (GCA), added to the overall trait mean, in the first and second growing season for the traits incidence and severity of E. turcicum (IET, SET), B. maydis (IBM, SBM), $P$. polysora (IPP, SPP), and grain yield (GY) and popping expansion (PE).

\begin{tabular}{|c|c|c|c|c|c|c|c|c|}
\hline \multirow{2}{*}{ Parents } & \multicolumn{8}{|c|}{$1^{\text {st }}$ season } \\
\hline & IET & SET & IBM & SBM & IPP & SPP & GY & PE \\
\hline L55 & 15.53 & 6.78 & 13.2 & 0.08 & 30.62 & 15.25 & 3385.90 & 31.11 \\
\hline L61 & 12.58 & 2.84 & 8.36 & 0.07 & 25.89 & 12.06 & 3265.31 & 31.31 \\
\hline L70 & 13.72 & 3.77 & 8.81 & 0.07 & 25.30 & 13.14 & 3240.61 & 32.58 \\
\hline L76 & 14.43 & 2.70 & 11.85 & 0.08 & 27.49 & 12.71 & 3364.63 & 32.05 \\
\hline L77 & 17.09 & 3.61 & 14.18 & 0.09 & 29.47 & 14.17 & 3378.01 & 32.27 \\
\hline L88 & 16.67 & 3.44 & 16.45 & 0.11 & 31.10 & 15.27 & 3406.71 & 30.45 \\
\hline P1 & 13.29 & 4.39 & 11.73 & 0.09 & 26.98 & 13.31 & 3519.61 & 32.39 \\
\hline P8 & 13.25 & 4.04 & 13.73 & 0.07 & 29.64 & 14.64 & 3339.81 & 33.52 \\
\hline \multirow{2}{*}{ Parents } & \multicolumn{8}{|c|}{$2^{\text {nd }}$ season } \\
\hline & IET & SET & IBM & SBM & IPP & SPP & GY & PE \\
\hline L55 & 34.65 & 7.49 & 18.06 & 0.25 & 0.88 & 0.06 & 3390.34 & 25.84 \\
\hline L61 & 30.56 & 4.81 & 15.47 & 0.12 & 1.09 & 0.07 & 3553.74 & 30.53 \\
\hline L70 & 28.98 & 5.42 & 16.04 & 0.17 & 0.81 & 0.05 & 3652.34 & 28.41 \\
\hline L76 & 13.70 & 2.09 & 16.52 & 0.17 & 0.87 & 0.05 & 3553.94 & 26.98 \\
\hline L77 & 14.14 & 2.42 & 22.66 & 0.53 & 0.65 & 0.03 & 3486.24 & 28.01 \\
\hline L88 & 16.68 & 2.52 & 25.72 & 0.54 & 0.61 & 0.05 & 3524.14 & 26.03 \\
\hline P1 & 26.37 & 5.00 & 23.50 & 0.56 & 0.51 & 0.05 & 3295.34 & 30.46 \\
\hline P8 & 21.74 & 4.11 & 23.88 & 1.30 & 1.00 & 0.05 & 3538.84 & 28.37 \\
\hline
\end{tabular}


Thus, in the first season, these lines were the parents that contributed most with favorable alleles to increase the disease resistance levels in the diallel crosses. In contrast, line L88 had the highest GCA estimates for the traits related to resistance against $B$. maydis and $P$. polysora. For E. turcicum, lines L77 and L55 contributed least to raise the resistance levels (Table 3). These lines tend to produce hybrids with higher susceptibility to these diseases. For grain yield (GY) and popping expansion (PE), no lines were found responsible for increasing the means of both traits simultaneously, which can be explained by the fact that these traits are negatively correlated (Rangel et al., 2011; Freitas et al. al., 2013; Cabral et al., 2015). In this way, line P8 had the highest GCA estimates for PE, increasing the mean of this trait in its crosses. For GY, the highest GCA estimates were observed in lines P1 and L88.

In the second season, lines L76 and L61 contributed most to the reduction of E. turcicum and $B$. maydis incidence and severity, respectively. As in the first season, parent L61 stood out as an important source of favorable alleles to favor B. maydis resistance. In relation to $P$. polysora, the lowest GCA estimates for this trait were observed in lines P1 and L77, which are the most promising (Table 3). In the second season, the GCA estimates for disease incidence and severity of the parents were generally higher than in the first, except in the case of polysora rust, for which the variability for GCA in the second growing season was not significant (Table 3 ).

According to Engelsing et al. (2011) and Nihei and Ferreira. (2012), environmental factors may influence the expression of resistance-related genes, possibly due to variations in latitude, temperature, relative air humidity and fertilization. In this study, environmental factors favored a higher intensity of $B$. maydis and $E$. turcicum in the second growing season, which caused differences in the GCA of the lines between the seasons. In this way, the selection of parents in the second season is more promising to distinguish resistant genotypes. On the other hand, for polysora rust resistance, the environment was unfavorable for selection of parents.

For GY, highest GCA estimates were found in lines L70 and L76, contributing to increase popcorn grain yield in the second season. Similarly, highest GCA estimates for PE were observed in lines L61 and P1, which are therefore considered promising for breeding programs, if increased popping expansion is targeted (Table 3).

Lines L61, L70 and L76 had the best GCA values for the set of variables, in both growing seasons, demonstrating that these genotypes are very promising and can be used in popcorn breeding programs as sources of favorable alleles for the development of cultivars that are more resistant to E. turcicum, B. maydis and $P$. polysora, along with high gains for grain yield and popping expansion.

\section{Trait correlations with the genetic merits of the lines}

The correlation between traits based on the additive genetic merit (GCA+GCA x season) indicates the possibility of simultaneous trait selection for the parents to obtain faster results for two traits than with direct selection. However, the correlation between popcorn traits may differ due to the growing season, indicating that certain simultaneous gains between traits will occur because of the adaptation of a genotype to a given growing season. For this reason, the correlations of the genetic merit of the parents between traits within each season were estimated (Table 4).

The results of the first season showed a significant correlation between IBM and IPP $(r=$ 0.93, $\mathrm{p}<0.01)$, IBM and SPP $(\mathrm{r}=0.84, \mathrm{p}<0.01)$; and between IPP and SPP $(\mathrm{r}=0.81, \mathrm{p}<0.01)$. The high correlation between $B$. maydis and $P$. polysora incidence in the first growing season allows simultaneous gains with the selection of parents for resistance to only one disease. In breeding programs, simultaneous selection accelerates the process for more than one trait and, consequently, cultivars that are resistant to more than one disease can be developed.

In the second season, significant correlations were observed between IBM and $\operatorname{SBM}(r=0.75, p=0.03)$; and EIT and SET $(r=$ $0.96, \mathrm{p}<0.01)$. In this way, resistant parents for B. maydis and E. turcicum can be selected using only one trait - incidence or severity. Therefore, and for greater practicality, it is recommended to use incidence-related traits as the main variable in field experiments, under natural disease infection, as pointed out by Kurosawa et al. 2017. 
Table 4. Correlations between the estimates of additive genetic merit (GCA) for the first (upper diagonal) and second growing season (lower diagonal), for IET (\%), SET (\%), IBM (\%), SBM (\%), IPP (\%), SPP (\%), GY $\left(\mathrm{kg} \cdot \mathrm{ha}^{-1}\right)$ and PE $\left(\mathrm{mL} \cdot \mathrm{g}^{-1}\right)$.

\begin{tabular}{|c|c|c|c|c|c|c|c|c|}
\hline Traits & IET & IBM & IPP & SPP & SET & SBM & PE & GY \\
\hline IET & - & & & & & & & \\
\hline IBM & $-0.44^{\mathrm{ns}}$ & - & $0.93 * *$ & $0.84 * *$ & $0.21^{\mathrm{ns}}$ & & & \\
\hline IPP & & & - & $0.91^{* *}$ & $0.43^{\text {ns }}$ & & & \\
\hline SPP & & & & - & $0.61^{\mathrm{ns}}$ & & & \\
\hline SET & $0.96 * *$ & $-0.35^{\mathrm{ns}}$ & & & - & & & \\
\hline SBM & $-0.27^{\mathrm{ns}}$ & $0.75^{*}$ & & & $-0.18^{\mathrm{ns}}$ & - & & \\
\hline PE & $0.26^{\mathrm{ns}}$ & $-0.13^{n s}$ & & & $0.10^{\text {ns }}$ & $0.04^{\mathrm{ns}}$ & - & \\
\hline GY & & & & & & & & - \\
\hline
\end{tabular}

P value: ${ }^{* *} \mathrm{p}<0.01 ; * \mathrm{p}<0.05 ;{ }^{\text {ns }}$ non-significant.

\section{Genotype value of the hybrids}

For the disease-related traits in both growing seasons, at least one line with low GCA estimate was observed among the hybrid combinations with lowest of $h_{i j l}$ estimates (Table 5). This shows that the desirable effect of allelic accumulation of the parents resulted in good gene complementation in the hybrid combinations. It is desirable that the hybrid combinations with more favorable $S C A$ estimates involve at least one of the parents with the most favorable GCA effect (Cruz et al., 2012).
The traits popping expansion, yield and disease resistance are considered the most important in popcorn (Scapim et al., 2010) and the development of genotypes that aggregate all these traits is therefore fundamental for producers. In this aspect, the $h_{i j l}$ estimates of the hybrids L61 x L70, L70 x L77, L61 x L76, L70 x L76, L61 x P1 and L61 x P8 were the lowest for the studied disease group in the first growing season, indicating these hybrids as promising. However, only hybrids L70 x L76, L70 x L77, L61 x P1 and L61 x P8 had high $h_{i j l}$ estimates for GY and PE as well (Table 5).

Table 5. Estimates of the genotypic value of the hybrids $\left(h_{i j l}\right)$, added to the overall trait mean, for the traits incidence and severity to E. turcicum (IET, SET), B. maydis (IBM, SBM), P. polysora (IPP, SPP), grain yield (GY) and popping expansion (PE) in the first and second growing season.

\begin{tabular}{|c|c|c|c|c|c|c|c|c|}
\hline \multirow{3}{*}{ Genotype } & \multicolumn{2}{|c|}{ IET } & \multicolumn{2}{|c|}{ SET } & \multicolumn{2}{|c|}{ IBM } & \multicolumn{2}{|c|}{ SBM } \\
\hline & \multicolumn{2}{|c|}{ season } & \multicolumn{2}{|c|}{ season } & \multicolumn{2}{|c|}{ season } & \multicolumn{2}{|c|}{ season } \\
\hline & $1^{\text {st }}$ & $2^{\text {nd }}$ & $1^{\text {st }}$ & $2^{\text {nd }}$ & $1^{\text {st }}$ & $2^{\text {nd }}$ & $1^{\text {st }}$ & $2^{\text {nd }}$ \\
\hline L55xL61 & 14.27 & 45.36 & 5.06 & 8.36 & 5.61 & 9.97 & 0.04 & 0.02 \\
\hline L55xL70 & 13.30 & 44.96 & 5.43 & 8.59 & 7.35 & 10.51 & 0.04 & 0.03 \\
\hline L55xL76 & 10.60 & 18.07 & 3.30 & 3.81 & 11.87 & 13.10 & 0.05 & 0.06 \\
\hline L55xL77 & 15.39 & 13.84 & 6.10 & 3.76 & 14.64 & 18.77 & 0.06 & 0.25 \\
\hline L55xL88 & 18.47 & 21.54 & 5.11 & 3.63 & 14.43 & 20.12 & 0.33 & 0.14 \\
\hline L55xP1 & 13.88 & 45.93 & 7.21 & 9.52 & 8.98 & 19.41 & 0.06 & 0.22 \\
\hline L55xP8 & 13.67 & 21.55 & 6.94 & 6.37 & 14.41 & 20.45 & 0.06 & 0.50 \\
\hline L61xL70 & 17.81 & 48.18 & 3.95 & 8.31 & 5.26 & 11.28 & 0.04 & 0.04 \\
\hline L61xL76 & 7.64 & 14.75 & 1.30 & 1.92 & 6.95 & 9.12 & 0.06 & 0.06 \\
\hline L61xL77 & 5.77 & 6.72 & 0.95 & 0.87 & 8.14 & 15.56 & 0.09 & 0.07 \\
\hline L61xL88 & 8.06 & 13.05 & 0.96 & 1.60 & 8.62 & 17.93 & 0.04 & 0.04 \\
\hline L61xP1 & 6.14 & 25.60 & 2.29 & 4.14 & 4.95 & 13.38 & 0.05 & 0.02 \\
\hline L61xP8 & 7.56 & 27.97 & 2.45 & 5.05 & 5.81 & 14.72 & 0.05 & 0.09 \\
\hline L70xL76 & 10.82 & 15.87 & 3.31 & 3.25 & 6.15 & 9.26 & 0.06 & -0.05 \\
\hline
\end{tabular}


Table 5. Estimates of the genotypic value of the hybrids $\left(h_{i j l}\right)$, added to the overall trait mean, for the traits incidence and severity to E. turcicum (IET, SET), B. maydis (IBM, SBM), P. polysora (IPP, SPP), grain yield $(\mathrm{GY})$ and popping expansion (PE) in the first and second growing season (Continuation)

\begin{tabular}{|c|c|c|c|c|c|c|c|c|}
\hline \multirow{3}{*}{ Genotype } & \multicolumn{2}{|c|}{ IET } & \multicolumn{2}{|c|}{ SET } & \multicolumn{2}{|c|}{ IBM } & \multicolumn{2}{|c|}{ SBM } \\
\hline & \multicolumn{2}{|c|}{ season } & \multicolumn{2}{|c|}{ season } & \multicolumn{2}{|c|}{ season } & \multicolumn{2}{|c|}{ season } \\
\hline & $1^{\text {st }}$ & $2^{\text {nd }}$ & $1^{\text {st }}$ & $2^{\text {nd }}$ & $1^{\text {st }}$ & $2^{\text {nd }}$ & $1^{\text {st }}$ & $2^{\text {nd }}$ \\
\hline L70xL77 & 7.03 & 5.04 & 1.39 & 0.95 & 6.91 & 17.02 & 0.07 & 0.09 \\
\hline L70xL88 & 10.90 & 13.35 & 1.64 & 2.06 & 9.81 & 18.48 & 0.06 & 0.12 \\
\hline L70xP1 & 11.77 & 29.41 & 4.49 & 5.90 & 5.37 & 17.84 & 0.06 & 0.05 \\
\hline L70xP8 & 9.44 & 23.28 & 3.35 & 4.90 & 8.04 & 17.51 & 0.09 & 0.17 \\
\hline L76xL77 & 12.09 & 2.33 & 2.90 & 0.36 & 11.28 & 16.04 & 0.09 & 0.06 \\
\hline L76xL88 & 14.59 & 7.73 & 2.22 & 0.62 & 13.75 & 21.07 & 0.10 & 0.12 \\
\hline L76xP1 & 9.39 & 9.51 & 3.62 & 2.17 & 9.37 & 17.70 & 0.05 & 0.15 \\
\hline L76xP8 & 7.79 & 8.41 & 1.68 & 1.09 & 10.82 & 18.73 & 0.13 & 0.26 \\
\hline L77xL88 & 16.41 & 4.64 & 2.28 & -0.01 & 17.42 & 27.57 & 0.10 & 0.26 \\
\hline L77xP1 & 11.78 & 12.21 & 3.51 & 2.44 & 11.64 & 23.59 & 0.10 & 0.61 \\
\hline L77xP8 & 12.71 & 6.55 & 2.99 & 1.48 & 14.20 & 25.60 & 0.07 & 1.34 \\
\hline L88xP1 & 12.96 & 16.62 & 2.51 & 2.67 & 15.02 & 30.54 & 0.20 & 0.92 \\
\hline L88xP8 & 15.21 & 12.45 & 5.01 & 2.98 & 18.13 & 31.62 & 0.06 & 1.85 \\
\hline P1xP8 & 13.35 & 19.31 & 5.31 & 5.37 & 14.91 & 26.73 & 0.07 & 1.03 \\
\hline L55xL61 & 27.37 & 1.38 & 12.27 & 0.17 & 3302.29 & 3474.31 & 31.70 & 28.80 \\
\hline L55xL70 & 27.88 & 1.14 & 12.81 & 0.02 & 3480.87 & 3750.99 & 31.56 & 25.24 \\
\hline L55xL76 & 29.81 & 0.79 & 14.96 & 0.04 & 3841.81 & 3882.34 & 32.64 & 23.59 \\
\hline L55xL77 & 32.49 & 0.56 & 15.87 & 0.03 & 3074.09 & 3057.53 & 31.18 & 26.35 \\
\hline L55xL88 & 33.71 & 0.69 & 16.68 & 0.06 & 3621.80 & 3599.89 & 32.46 & 26.93 \\
\hline L55xP1 & 29.00 & 0.52 & 13.49 & 0.04 & 3196.31 & 2827.93 & 29.35 & 28.11 \\
\hline L55xP8 & 34.18 & 1.23 & 16.35 & 0.06 & 2821.10 & 2920.34 & 30.15 & 23.27 \\
\hline L61xL70 & 23.75 & 0.90 & 11.33 & 0.04 & 2633.58 & 3187.01 & 32.42 & 30.78 \\
\hline L61xL76 & 24.81 & 1.63 & 10.75 & 0.06 & 4204.83 & 4561.54 & 32.67 & 31.91 \\
\hline L61xL77 & 26.05 & 1.14 & 13.79 & 0.06 & 3895.82 & 4175.34 & 33.65 & 30.78 \\
\hline L61xL88 & 28.42 & 0.68 & 13.32 & 0.03 & 4086.31 & 4381.94 & 30.43 & 28.86 \\
\hline L61xP1 & 24.28 & 1.00 & 12.47 & 0.13 & 3792.34 & 3722.76 & 33.79 & 34.54 \\
\hline L61xP8 & 25.58 & 1.21 & 10.73 & 0.04 & 3810.01 & 4141.29 & 34.21 & 31.97 \\
\hline L70xL76 & 23.85 & 0.90 & 13.22 & 0.06 & 4115.13 & 4605.04 & 32.54 & 26.73 \\
\hline L70xL77 & 25.71 & 0.70 & 14.59 & 0.04 & 4386.84 & 4771.64 & 33.97 & 28.64 \\
\hline L70xL88 & 27.50 & 0.84 & 15.09 & 0.12 & 4758.33 & 5167.74 & 33.67 & 29.50 \\
\hline L70xP1 & 22.88 & 0.63 & 13.15 & 0.06 & 3737.59 & 3807.34 & 34.95 & 31.90 \\
\hline L70xP8 & 27.02 & 0.75 & 12.66 & 0.01 & 3865.63 & 4347.88 & 34.08 & 27.36 \\
\hline L76xL77 & 28.73 & 0.61 & 12.79 & 0.01 & 4443.05 & 4600.85 & 31.28 & 24.50 \\
\hline L76xL88 & 30.32 & 0.65 & 14.70 & 0.09 & 4248.77 & 4425.11 & 29.56 & 24.04 \\
\hline L76xP1 & 25.13 & 0.47 & 11.55 & 0.02 & 4215.93 & 4019.64 & 33.38 & 31.22 \\
\hline L76xP8 & 29.09 & 1.32 & 15.90 & 0.13 & 3933.59 & 4183.37 & 34.47 & 29.64 \\
\hline L77xL88 & 32.66 & 0.41 & 15.89 & 0.03 & 4552.71 & 4623.61 & 32.00 & 26.39 \\
\hline L77xP1 & 27.80 & 0.28 & 13.12 & 0.01 & 3405.41 & 3151.47 & 34.09 & 32.12 \\
\hline L77xP8 & 30.17 & 1.06 & 15.42 & 0.09 & 4066.81 & 4232.17 & 33.63 & 27.52 \\
\hline L88xP1 & 29.44 & 0.31 & 15.59 & 0.03 & 4450.01 & 4184.32 & 34.20 & 31.09 \\
\hline L88xP8 & 33.26 & 0.72 & 18.31 & 0.05 & 4097.39 & 4260.17 & 32.08 & 25.25 \\
\hline P1xP8 & 27.90 & 0.56 & 13.85 & 0.03 & 3595.02 & 3423.09 & 35.04 & 31.80 \\
\hline
\end{tabular}


In the second growing season, not many combinations could be selected with simultaneous gains for disease resistance and agronomic traits. However, some hybrids were promising for selection for higher grain yield and popping expansion, and reduction of incidence and severity of at least one disease. In this respect, the combinations L61 x L77, L76 x P1 and L77 x P1 stood out with the lowest estimates for E. turcicum and with high positive estimates for GY and PE. Likewise, the combinations L61 x L76 and L61 x L70 were promising for their high positive PE and GY estimates and lower estimates for the traits related to B. maydis resistance.

In both growing seasons, the $h_{i j l}$ estimates of the hybrids L61 x L76, L61 x L77 and L76 x P1 were low for the evaluated disease set and high for grain yield, indicating that they are the most indicated for official recommendations for cultivation in both evaluated seasons.

\section{Correlation between traits with the genotype value of the hybrids}

The correlations with the genotypic value of the hybrids $\left(h_{i j l}\right)$ were estimated among the traits evaluated in two growing seasons, to analyze the degree of association of these traits for hybrid selection. These estimates were only considered in cases in which the variance components of the genotypic value were statistically higher than zero $(\mathrm{p}<0.05)$. Therefore, the correlations with SBM were not computed in the first growing season, while in the second season, the correlations with IPP and SPP were not shown (Table 6).

Table 6. Correlations between estimates of the genotypic value of the hybrids $\left(h_{i j l}\right)$, for the first growing season (upper diagonal) and second growing season (lower diagonal), for EIT (\%), SET (\%), IBM), SBM (\%), IPP (\%), SPP (\%), GY (kg.ha $\left.{ }^{-1}\right)$ and PE (mL.g $\left.\mathrm{g}^{-1}\right)$.

\begin{tabular}{|c|c|c|c|c|c|c|c|c|}
\hline Traits & IET & IBM & IPP & SPP & SET & SBM & PE & GY \\
\hline IET & - & $0.52 * *$ & $0.55^{* *}$ & $0.40^{*}$ & $0.64 * *$ & & $-0.41^{*}$ & $-0.37^{*}$ \\
\hline IBM & $-0.41^{*}$ & - & $0.87^{*}$ & $0.80 * *$ & $0.23^{\text {ns }}$ & & $-0.19^{n s}$ & $0.15^{\mathrm{ns}}$ \\
\hline IPP & & & - & $0.81^{* *}$ & $0.37^{*}$ & & $-0.46 * *$ & $-0.06^{\mathrm{ns}}$ \\
\hline SPP & & & & - & $0.20^{\mathrm{ns}}$ & & $-0.14^{\mathrm{ns}}$ & $0.13^{\text {ns }}$ \\
\hline SET & $0.96 * *$ & $-0.32^{\mathrm{ns}}$ & & & - & & $-0.36^{n s}$ & $-0.70 * *$ \\
\hline SBM & $-0.25^{n s}$ & $0.82^{* *}$ & & & $-0.12^{\mathrm{ns}}$ & - & & \\
\hline PE & $0.13^{\text {ns }}$ & $-0.09^{n s}$ & & & $0.04^{\text {ns }}$ & $-0.10^{\text {ns }}$ & - & $0.25^{\mathrm{ns}}$ \\
\hline GY & $-0.59 * *$ & $0.55^{\mathrm{ns}}$ & & & $-0.70 * *$ & $-0.07^{n s}$ & $-0.05^{\mathrm{ns}}$ & - \\
\hline
\end{tabular}

P value: ${ }^{* *} \mathrm{p}<0.01 ; * \mathrm{p}<0.05 ;$ ns non-significant.

In relation to the correlation estimate of grain yield (GY) with the other traits in both growing seasons, there was a significant and negative association between EIT $(r=-0.37, \mathrm{p}$ $<0.05)$ and SET $r=-0.70, \mathrm{p}<0.01)$ in the first (above the diagonal) and in the second growing season (below the diagonal) for trait SET ( $\mathrm{r}=$ $0.70, p<0.01$ ) (Table 6). This relationship shows that the higher the intensity and severity of $E$. turcicum, the lower the grain yield of the crop. Negative correlations between grain yield and leaf diseases in maize were reported by Santos et al. (2002) and Dudienas et al. (2013).

In the first growing season, the incidence of B. maydis was positively correlated and statistically higher than zero $(\mathrm{p}<0.01)$, with EIT $(r=0.52)$, IPP $(r=0.87)$ and SPP $(r=0.80)$. Along this line, hybrids can be selected for these traits simultaneously, resulting in the development of genotypes that confer resistance to the main foliar diseases affecting popcorn.

In the second growing season, there was a significant and positive correlation between IBM and SMB $(r=0.82, p<0.01)$; $(\mathrm{P}<0.01)$, i.e., the higher the proportion of diseased leaves, the greater the percentage of injured leaf area on the leaf of the first ear for these traits. According to Amorim (1995) and Bergamin Filho (1996), for leaf diseases, the severity adequately represents the disease level, although the determination is somewhat unreliable, due to the high subjectivity of estimation and the need of training or continuous use of a diagrammatic scale (Bordin et al., 2018). Analogously to the GCA correlation between these traits in the second season, it is possible to recommend and 
use only the incidence of $B$. maydis and $E$. turcicum to discriminate the most resistant hybrids, optimizing the time of disease evaluation in the field. However, new evaluations are required to extrapolate these data to other sets of genotypes.

\section{Conclusions}

The non-additive gene effects are more important for the traits related to E. turcicum, $B$. maydis and $P$. polysora, popping expansion and grain yield, in the set of evaluated genotypes. There was no reciprocal effect on the traits associated with disease resistance and on the main agronomic traits. In both growing seasons, the genotypes L61, L70 and L76 increased the resistance level to E. turcicum, B. maydis and $P$. polysora more than the other lines and induced satisfactory gains in GY and PE. The combinations L61 x L76, L61 x L77 and L76 x $\mathrm{P} 1$ are promising for cultivation in both seasons, targeting a reduction in the levels of several diseases and increases in grain yields. The high correlation between the traits of one of the diseases (B. maydis and E. turcicum) in the second growing season indicated that the parents and hybrids can be selected based only on the respective disease incidence.

\section{References}

Agroceres. 1996. Guia Agroceres de sanidade. São Paulo, 72p.

Amaral Júnior, AT; Santos, A; Gerhardt, I.F.S; Kurosawa, R.N.F; Moreira, N.F.; Pereira, M.G.; Gravina, G.A.; Silva, F.H.L. 2016. Proposal of a super trait for the optimum selection of popcorn progenies based on path analysis. Genetics and Molecular Research, 15(4).

Amorim, L. 1995. Avaliação de doenças. In: Bergamin Filho, A., Kimati, H., Amorim, L. Manual de fitopatologia, 3ed. Agronômica Ceres, São Paulo, p.647-671.

Ayiga-Aluba, J.; Edema, R.; Tusiime, G.; Asea, G.; Gibson, P. 2015. Response to two cycles of S1 recurrent selection for turcicum leaf blight in an open-pollinated maize variety population (Longe 5). Advances in Applied Science Research, 6(12):4-12.

Babu, R.; Nair, S.K.; Kumar, A.; Rao, H.S.; Verma, P.; Gahalain, A.; Gupta, H.S. 2006. Mapping QTLs for popping ability in a popcorn x flint corn cross. Theoretical and Applied Genetics, 112(7):1392-1399.

Bergamim Filho, A.; Amorim, L. 1996. Doenças de plantas tropicais: epidemiologia e controle econômico, Agronômica Ceres, São Paulo.

Bordin, L.C.; Casa, R.T.; Marcuzzo, L.L.; Souza, C.A.; Gheller, A.; Zancan, R.L; Stoltz, J.C. 2018. Relações lineares entre incidência e severidade foliar em patossistema multiplo de manchas foliares em arroz irrigado. Summa Phytopathologica, 42(3):239-242.

Brien, C. 2016. asremIPlus: Augments the Use of "ASReml-R" in Fitting Mixed Models. Available from URL. https://cran.rproject.org/package=asremlPlus

Butler, D.G.; Cullis, B.R.; Gilmour, A.R.; Gogel, B.J. 2009. asreml-R reference manual. The State of Queensland, Department of Primary Industries and Fisheries, Brisbane.

Cabral, P.D.S.; Amaral Júnior, A.T. do; Viana, A.P.; Vieira, H.D.; Freitas, I.L.J.; Vittorazzi, C.; Vivas, M. 2015. Combining ability between tropical and temperate popcorn lines for seed quality and agronomic traits. Australian Journal of Crop Science, 9(4):256-263. 
Carson, M.L. 2006. Response of a maize synthetic to selection for components of partial resistance to Exserohilum turcicum. Plant Disease, 90(7):910-914

Carson, M.L. 1995. A new gene in maize conferring the chlorotic halo reaction to infection by Exserohilum turcicum. Plant Disease, 79(7):717-720.

Carson, M.L. 2001. Inheritance of resistance to Phaeosphaeria leaf spot of maize. Plant Disease, 85(7):798-800.

Carson, M.L.; Stuber, C.W.; Senior, M.L. 2004. Identification and mapping of quantitative trait loci conditioning resistance to southern leaf blight of maize caused by Cochliobolus heterostrophus race 0 . Phytopathology, 94(8):862-867.

Chen, G.; Wang, X.; Long, S.; Jaqueth, J.; Li, B.; Yan, J.; Ding, J. 2016. Mapping of QTL conferring resistance to northern corn leaf blight using high-density SNPs in maize. Molecular breeding, 36(1):4.

Chester, K.S. 1950. Plant disease losses: their appraisal and interpretation, 193:189-362

Colombo, G.A.; Vaz-de-Melo, A.; Taubinger, M.; de Castro Tavares, R.; Ribeiro da Silva, R. 2014. Análise dialélica para resistência a ferrugem polissora em milho em diferentes níveis de adubação fosfatada. Bragantia, 73(1).

Costa, D.F.; Vieira, B.S.; Lopes, E.A.; Moreira, L.C.B. 2012. Aplicação de fungicidas no controle de doenças foliares na cultura do milho. Revista Brasileira de Milho e Sorgo, 11(1): 98-105.

Cruz, C.D.; Regazzi, A.J.; Carneiro, P.C.S. 2012. Modelos biométricos aplicados ao melhoramento genético, $4^{\circ}$ ed. UFV, Viçosa, Brasil. $514 p$.

Ding, J.; Ali, F.; Chen, G.; Li, H.; Mahuku, G.; Yang, N.; Narro, L.; Magorokosho, C.; Makumbi, D.; Yan, J. 2015. Genome-wide association mapping reveals novel sources of resistance to northern corn leaf blight in maize. BMC Plant Biology, 15(1):206.

Dudienas, C.; Fantin, G.M.; Aildson, P.; Duarte, A.P.; Ticelli, M.; Bárbaro, I.M.; Freitas, R.S.; Leão, P.C.L.; Cazentini Filho, G.; Bolonhezi, D.; Pântano, A.P. 2013. Severidade de ferrugem polissora em cultivares de milho e seu efeito na produtividade. Summa Phytopathologica, 39(1):16-23.

Engelsing, M.J.; Rozzetto, D.S.; Coimbra, J.L.M.; Zanin, C.G.; Guidolin, A.F. 2011. Capacidade de combinação em milho para resistência a Cercospora zeae-maydis. Revista Ciência Agronômica, 42(1):232-241.

Ferguson, L.M.; Carson, M.L. 2007. Temporal variation in Setosphaeria turcica between 1974 and 1994 and origin of races 1, 23, and 23N in the United States. Phytopathology, 97(11):15011511.

Freitas Júnior, S.P.; Amaral Júnior, A.T.; Pereira, M.G.; Cruz, C.D.; Scapim, C.A. 2006. Capacidade combinatória em milho-pipoca por meio de dialelo circulante. Pesquisa Agropecuária Brasileira, 41(11):1599-1607.

Freitas, I.L.J.; Amaral Júnior, A.T.; Viana, A.P.; Pena, G.F.; Cabral, P.S.; Vittorazzi, C.; Silva, T.R.C. 2013. Ganho genético avaliado com índices de seleção e com REML/Blup em milho-pipoca. Pesquisa Agropecuária Brasileira, 48(11):1464-1471. 
Guimarães, P.S.; Paterniani, M.E.A.G.Z.; Dudienas, C.; Lüders, R.R.; Gallo, P.B. 2009. Capacidade combinatória para resistência à mancha branca em linhagens endogâmicas de milho. Summa Phytopathologica, 35(4):282-287.

Hallauer, A.R.; Miranda Filho, J.D.; Carena, M.J. 2010. Breeding plans. In Quantitative genetics in maize breeding, Springer, New York, NY, p.577-653.

Hurni, S.; Scheuermann, D.; Krattinger, S.G.; Kessel, B.; Wicker, T.; Herren, G.; Fitze, M.N.; Breen, J.; Presterl, T.; Ouzunova, M.; Keller, B. 2015. The maize disease resistance gene Htn1 against northern corn leaf blight encodes a wall-associated receptor-like kinase. Proceedings of the National Academy of Sciences, 112(28):8780-8785.

Hussain, H.; Raziq, F.; Khan, I.; Shah, B.; Altaf, M.; Attaullah Ullah, W.; Naeem, A.; Adnan, M.; Junaid, K.; Shah, S.R.A.; Iqbal, M. 2016. Effect of Bipolaris maydis (Y. Nisik \& C. Miyake) shoemaker at various growth stages of different maize cultivars. Journal of Entomology and Zoology Studies, 4(2):439-444.

Ishfaq, A.; Dar, Z.A.; Lone, A.A.; Ali, G.; Gazal, A.; Hamid, B.; Mohiddin, F.A. 2014. Disease reaction studies of maize (Zea mays L.) against turcicum leaf blight involving indigenously identified cytosterile source. African Journal of Microbiology Research, 8(27):2592-2597.

James, W.C. 1971. A manual of assessment keys of plant diseases. Canada Department of Agriculture Publication, 1458, 80p.

Kaefer, K.A.C.; Schuelter, A.R.; Schuster, I.; Marcolin, J.; Vendruscolo, E.C.G. 2017. Association mapping and genetic control for northern leaf blight ('Exserohilum turcicum') resistance in maize lines. Australian Journal of Crop Science, 11(10):1346-1353.

Kumar, B.; Hooda, K.S.; Gogoi, R.; Kumar, V.; Kumar, S.; Abhishek, A.; Bhati, P.; Sekhar, J.C.; Yathish, K.R.; Singh, V.; Das, A.; Mukri, G.; Varghese, E.; Kaur, H.; Malik, V.; Yadav, O.P. 2016. Inheritance study and stable sources of maydis leaf blight (Cochliobolus heterostrophus) resistance in tropical maize germplasm. Cereal Research Communications, 44(3):424-434.

Kurosawa, R.D.N.F.; Vivas, M.; Amaral, A.T.D.; Ribeiro, R.M.; Miranda, S.B.; Pena, G.F.; Leite, J.T.; Mora, F. 2017. Popcorn germplasm resistance to fungal diseases caused by Exserohilum turcicum and Bipolaris maydis. Bragantia, 77(1):36-47.

Kurosawa, R.N.; Vivas, M.; Júnior, A.T.A.; dos Santos, A.; Mafra, G.S.; Guimarães, A.G.; Schwantes, I.A. 2016. Reaction of popcorn germplasm to polysora rust under field conditions and natural inoculation. Tropical Plant Pathology, 41(6):415-422.

Li, Y.L.; Dong, Y.B.; Niu, S.Z.; Cui, D.Q. 2007. QTL for popping characteristics in popcorn. Plant breeding, 126(5):509-514.

Lopes, M.T.G.; Lopes, R.; Brunelli, K.R.; Silva, H.P.; Matiello, R.R.; Camargo, L.E.A. 2007. Controle genético da resistência à mancha-de-Phaeosphaeria em milho. Ciência Rural, 37(3):605-611.

Mubeen, S.; Rafique, M.; Munis, M.F.H.; Chaudhary, H.J. 2017. Study of southern corn leaf blight (SCLB) on maize genotypes and its effect on yield. Journal of the Saudi Society of Agricultural Sciences, 16(3):210-217. 
Muiru, E.; Koopmann, B.; Tiedemann, A.V.; Mutitu, E.W.; Kimenju, W. 2010. Race Typing and Evaluation of Aggressiveness of Exserohilum turcicum Isolates of Kenyan, German and Austrian Origin. World Journal of Agricultural Sciences, 6(3):277-284.

Nihei, T.H.; Ferreira, J.M. 2012. Análise dialélica de linhagens de milho com ênfase na resistência a doenças foliares. Pesquisa Agropecuária Brasileira, 47(3):369-377.

Ogliari, J.B.; Guimarães, M.A.; Giraldi, I.O.; Carmargo, L.E.A. 2007. New resistance genes in the Zea mays: Exserohilum turcicum pathosystem. Genetics and Molecular Biology. 28(3):435439.

Oliveira, G.H. 2016. Capacidade combinatória e correlação em populações de milho-pipoca (Tese: Doutorado em Agronomia: Genética e Melhoramento de Plantas), 61p, Universidade Estadual Paulista- UNESP, Câmpus de Jaboticabal, São Paulo.

Oliveira, L.R.D.; Miranda, G.V.; De Lima, R.O.; Souza, L.V.D.; Galvão, J.C.C.; Santos, I.C.D. 2011. Combining ability of tropical maize cultivars in organic and conventional production systems. Ciência Rural, 41(5):739-745.

Paterniani, M.E.A.G.Z.; Sawazaki, E.; Dudienas, C.; Duarte, A.P.; Gallo, P.B. 2000. Diallel crosses among maize lines with emphasis on resistance to foliar diseases. Genetics and Molecular Biology, 23(2):381-385.

Pereira, M.G.; Amaral Júnior, A.T. 2001. Estimation of genetic components in popcorn based on the nested design. Crop breeding and applied biotechnology, 1(1):3-10.

R Core Team. 2014. R: A Language and Environment for Statistical Computing. Avaliable from URL. http://www.r-project.org/.

Rangel, R.M.; Amaral Júnior, A.T.; Gonçalves, L.S.; Freitas Júnior, S.P.; Candido, L.S. 2011. Análise biométrica de ganhos por seleção em população de milho-pipoca de quinto ciclo de seleção recorrente. Revista Ciência Agronômica, 42(2):473-481.

Rangel, R.M.; Amaral Júnior, A.T.; Viana, A.P.; Júnior, S.D.P.F.; Pereira, M.G. 2007. Prediction of popcorn hybrid and composite means. Crop breeding and applied biotechnology, 7(3):287295.

Ribeiro, R.M.; Amaral Júnior, A.T.; Pena, G.F.; Vivas, M.; Kurosawa, R.N.; Gonçalves, L.S.A. 2016. History of northern corn leaf blight disease in the seventh cycle of recurrent selection of an UENF-14 popcorn population. Acta Scientiarum Agronomy, 38(4):447-455.

Santos, P.G.; Juliatti, F.C.; Buiatti, A.L.; Hamawaki, O.T. 2002. Avaliação do desempenho agronômico de híbridos de milho em Uberlândia, MG. Pesquisa Agropecuária Brasileira, 37(5):597-602.

Scapim, C.A.; Amaral Júnior, A.T.; Vieira, R.A.; Moterle, L.M.; Texeira, L.R.; Viganó, J.; Sandoval Júnior, G.B. 2010. Novos compostos de milho-pipoca para o Brasil. Semina: Ciências Agrárias, Londrina, 31(2):321-330.

Teixeira, F.F.; Portugal, A.F., Oliveira, M.S.; Silva, D.D.; Guimaraes, L.J.M.; Guimaraes, P.D.O.; Parentoni, S.N. 2017. Pré-melhoramento de milho para resistência à mancha-branca e à ferrugem-polissora. Embrapa Milho e Sorgo, 16(2):273-286. 
Vieira, R.A.; Tessmann, D.J.; Hata, F.T.; Souto, E.R.; Mesquini, R.M. 2009. Resistência de híbridos de milho-pipoca a Exserohilum turcicum, agente causal da helmintosporiose do milho. Scientia Agraria. 10(5):391-395.

Vieira, R.A.; Mesquini, R.M.; Silva, C.N.; Hata, F.T.; Tessmann, D.J.; Scapim, C.A. 2014. A new diagrammatic scale for the assessment of northern corn leaf blight. Crop Protection, 56:55-57.

Vieira, R.A.; Scapim, C.A.; Moterle, L.M.; Tessmann, D.J.; Amaral Júnior, A.T.; Gonçalves, L.A.S. 2012. The breeding possibilities and genetic parameters of maize resistance to foliar diseases. Euphytica, 185(3):325-336.

Vieira, R.A.; Scapim, C.A.; Tessmann, D.J.; Hata, F.T. 2011. Análise dialélica da produtividade, capacidade de expansão e resistência à ferrugem-polissora em linhagens de milho-pipoca. Revista Ciência Agronômica, 42(3):774-780.

Vivek, B.; Odongo, O.; Njuguna, J.; Imanywoha, J.; Bigirwa, G.; Diallo, A.; Pixley, K. 2010. Diallel analysis of grain yield and resistance to seven diseases of African maize (Zea mays L.) inbred lines. Euphytica. 172(3): 329-340.

Wang, P.; Souma, K.; Kobayashi, Y.; Iwabuchi, K.; Sato, C.; Masuko, T. 2010. Influences of Northern Leaf Blight on corn silage fermentation quality, nutritive value and feed intake by sheep. Animal Science Journal, 81(4):487-493.

Wang, X.; Zhang, Y.; Xu, X.; Li, H.; Wu, X.; Zhang, S.; Li, X. 2014. Evaluation of maize inbred lines currently used in Chinese breeding programs for resistance to six foliar diseases. The Crop Journal, 2(4):213-22. 